\title{
Influence of molybdenum and tungsten on the enzymatic activity of molybdenum enzymes
}

\author{
Gadilgereyeva B.Zh.*, Beisekova M.K., Kurmanbayeva A.B., Amanbayeva U.I., \\ Akbassova A.Zh., Zhangazin S.B., Masalimov Zh.K., Omarov R.T. \\ L.N. Gumilyov Eurasian National University, Nur-Sultan, Kazakhstan \\ *e-mail: gadilgereyeva_bzh@bk.ru
}

\begin{abstract}
A serious problem in the study of the role of heavy metals is that many of them in plants perform the function of vital trace elements. Therefore, when considering the toxicity of heavy metals, it is necessary to carefully assess the dependence of the reaction of plants on the concentrations of each metal and to analyze the different effects of heavy metals on wild and cultivated plants. The aim of our work was to study the effect of heavy metals such as molybdenum $\left(\mathrm{NaMoO}_{4} \cdot 2 \mathrm{H}_{2} \mathrm{O}\right)$ and tungsten $\left(\mathrm{Na}_{2} \mathrm{WO}_{4} \cdot 2 \mathrm{H}_{2} \mathrm{O}\right)$ in different concentrations $(0.1 \mathrm{mM}, 0.5 \mathrm{mM}$ and $1 \mathrm{mM})$ on the Moco containing enzymes in barley Hordeum vulgare L. seedlings.

Morphometric parameters of plants showed that Mo has a positive effect on growth of shoot and root systems, while W inhibited the growth, especially in the root system compared to their controls. Further in gel activity of Moco containing - AO and XDH enzymes were examined.
\end{abstract}

The results showed three different isoforms of aldehyde oxidase - AO1, AO2, and AO3 in the 7 days old barley roots. While in the leaves, AO activity was mild, there was no obvious distribution among individual isoforms. At high concentrations $(0.5 \mathrm{mM}$ and $1 \mathrm{mM}$ ) of tungsten, AO activity was completely disabled compare to other treatments. Adding different concentrations $(0.1 \mathrm{mM}, 0.5 \mathrm{mM}$ and $1 \mathrm{mM})$ of molybdenum salts increased $\mathrm{AO}$ activity of the $\mathrm{AO} 1$ isoform compared with the control samples.

Investigation of XDH activity showed higher intensity in Mo-treated $(0.1 \mathrm{mM}$ and $0.5 \mathrm{mM})$ seedlings, but high concentration $(1 \mathrm{mM})$ of Mo inhibited of XDH activity. In addition, tungsten treated seedlings with $1 \mathrm{mM}$ concentration had negative effect on activity of xanthine dehydrogenase compared to all other samples. 